\title{
The Impact of Transformational Leadership on Employee Performance: The Mediating Role of Employee Engagement in Selected Porcelain Manufacturing Companies in Sri Lanka
}

\author{
B.L.L.A. Balasuriya \\ University of Sri Jayewardenepura, Sri Lanka
}

\section{G.D.N. Perera}

University of Sri Jayewardenepura, Sri Lanka

\begin{abstract}
Transformational leadership is a concept and a belief in the contemporary business world which has proven results in employee development and organizational success. Leaders with transformational leadership behaviors coach and inspire their followers to achieve the targets by changing the value systems, culture and mindsets and sometimes being the role models to them. This paper aims to fill the existing research gap by examining the impact of transformational leadership on employee performance in the context of porcelain manufacturing companies in Sri Lanka, specifying the production worker level. Further this study investigates the mediating role of employee engagement between transformational leadership and employee performance. Thus, the current study contributes to the literature in the field of transformational leadership, employee performance and employee engagement. The study was conducted on a sample of 250 production workers in selected porcelain manufacturing companies in Sri Lanka. The data was analyzed using the analytical software SPSS version 23 and descriptive, correlation and regression analysis were conducted. The findings revealed that transformational leadership has a positive impact on employee performance and employee engagement and also employee engagement has a positive impact on employee performance. Importantly, employee engagement mediates the relationship between transformational leadership and employee performance. According to the findings of the study, it is concluded that transformational
\end{abstract}


leadership behaviors impact employee performance and employee engagement. This study adds to the current body of literature by providing insight into the impact of transformational leadership and employee engagement on employee performance in the porcelain manufacturing companies in Sri Lanka, and on the empirical ground, some of the findings and judgements of this study may be important to other organizations to make their employees engaged, develop and increase employee performance towards the organizations.

\section{Keywords:}

Employee Engagement, Employee Performance, Porcelain Manufacturing Companies, Production Workers, Transformational Leadership

\section{Introduction}

Human capital has become a source of success and revolution. The theory of transformational leadership describes the encouragement and motivation of an individual's positive behavior or enhanced thinking by leaders (Burns, 1978). It is evidenced that transformational leadership is productive under such conditions and a majority of existing literature supports the fact that leader practices contribute to organizational performance (Datche \& Hazel, 2015). These kinds of leaders assist followers to engage in their jobs and choicemaking process. Additionally, according to Ghafoor, Syed, \& Qureshi, (2011), transformational leadership also helps employees to feel that they matter a lot to the employer and the aim of the organization is their progress. The same authors have further described that these positive feelings towards the organization can enhance employees' organizational attitude and finally their quality of work. Lockwood (2007) stated that culture of the institute, conveying style, style of management, behavior of the leader, belief and admiration are the primary factors of employee engagement and these factors must be supported to build-up an engaging cultural behavior inside the workplace.

Currently, most of the organizations suffer with retrenchments and financial difficulties and are making an effort to uplift the organizational performances with limited employers and finances. Even under these circumstances, employee engagement still plays a greater role (Datche \& Hazel, 2015). Engagement is known as individual efforts and hard work for enhancing one's performances (Maslach, 2003). Engaged employees support the company towards success through increased performance. The leadership actions to motivate employees to perform over expectations by transforming their behaviors, attitudes and values 
is defined as a Transformation (Pillai \& Williams, 2004). Though several researches have been conducted to examine this said relationship and the mediating effect, there is a scarcity of research to address the impact of Transformational Leadership (TL) and Employee Engagement (EE) on Employee Performance (EP) in Sri Lanka. Therefore, the objectives of this study are to identify the (1) impact of TL on EP, (2) impact of EE on EP, (3) impact of TL on EE and (4) the mediating role of EE on TL and EP in selected porcelain manufacturing companies in Sri Lanka.

\section{Literature Review}

\section{Transformational Leadership}

Transformational leadership is defined as those actions displayed by a leader which enrich the value system of the followers, and convince them to reach beyond their expected performance (Han, Oh, \& Kang, 2020). TL is an encouraging and predominant style that has an impact on the outcomes and the actions of the people (Jyoti \& Bhau, 2015); (Butler, Stanton, \& Soane, 2015).This study defined TL as transforming the norms and values of the followers and inspiring them to elevate their desires for achievements, perform beyond presumption and self-development while promoting the development of the organization.

\section{Employee Performance}

Employee performance is mainly the outcomes attained and achievements made at work (Anitha, 2014). As cited in (Dixit \& Arrawati, 2018), EP refers to how ingeniously employees act in their jobs in accordance with the given targets of the company (Viswesvaran \& Ones, 2000). This study defined EP as "the expertise of the worker executing dominant work duties, employee behavior that supports the related environment in which the core tasks and duties are performed, the capacity of the worker to adjust to modifications in the work climate and the harmful behavior that negatively affects the well-being of the organization" (Koopmans, 2014). 


\section{Employee Engagement}

Xie (2006) explained that dedicated employees to a job, together with untiring efforts, who are faithful to the company and the leader, and who are assertive, is employee engagement. According to Sun (2019), logical employee engagement generally implies the relationship between employees and organizations, as the extent to which the employee understands their jobs and the roles in the department. This study defined EE from the viewpoint of Kahn (1990), “job engagement is best explained as a different measurement of inspirational concept contemplating the coincident investment of an individual's physical, cognitive, and emotional energy in active, full work performance" (Rich \& Crawford, 2010).

\section{Conceptual Framework}

Reviewing the prevailing literature, the conceptual framework of the study is depicted in Figure 1. In the conceptual framework TL was considered as the independent construct, EP as the dependent construct and EE as the mediator construct.

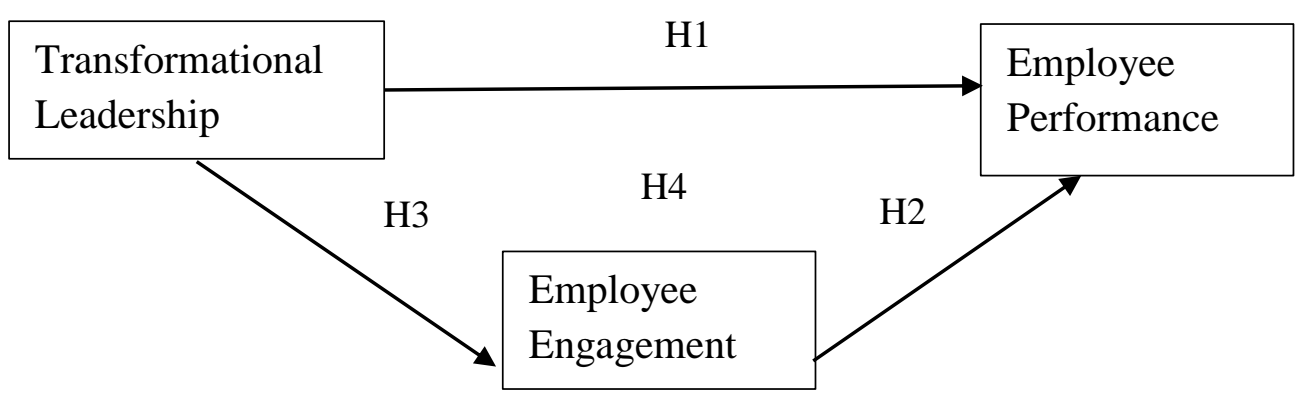

Figure 1: Conceptual Framework

Source: Author's compilation (2020)

\section{Transformational Leadership and Employee Performance}

The managers who transform the followers strive to enhance their perception by recalling their deep-rooted dreams and morals, such as liberty, fairness and compassion not based on sentiments such as avidity, resentment, and aversion (Rita, Payangan, Rante, Tuhumena, \& Erari, 2018). A considerable amount of enhancement in performance is related with those leaders who are considered to score higher on the measures of active individualized transformational and social processes of leadership (Groves \& LaRocca, 2011). The leader converts 
and encourages followers by personality, intellectual arousal, and individual consideration (Bacha, 2014).

Hence, the first hypothesis is developed as follows:

$\mathrm{H}_{1}$ : Transformational Leadership positively impacts on Employee Performance

\section{Employee Engagement and Employee Performance}

Some empirical studies have figured out that employee performance can be enhanced by employee engagement and also it can conclusively relate to lucrativeness, customer contentment, detention of workers and growth of the institute (Bates, 2004 ); (Baumruk, 2004); (Richman, 2006). Employee engagement is one of the most effective factors which leads to higher employee performance (Macey , Schneider, \& Bar, 2009); (Mone \& London, 2010), as well as predict the output and organizational success (Saks, 2006), (Macey , Schneider, \& Bar, 2009) and (Perera \& Wijewardene, 2019). Hence, the second hypothesis is developed as follows:

$\mathrm{H}_{2}$ : Employee Engagement positively impacts on Employee Performance

\section{Transformational Leadership and Employee Engagement}

Much scholarly attention has been given to the relationship between transformational leadership and employee engagement at work (Zhu, Avolio, \& Walumbwa, 2009); (Salanova, Lorente, Chambel, \& Martı'nez, 2011). Research findings by Devi \& Narayanamma (2016) have confirmed that there is a notable constructive relationship between transformational leadership and employee engagement.

Transformational leadership is an essential antecedent of work engagement and the relationship between transformational leadership and employee work engagement is a type of relationship to be considered for further studies Pourbarkhordari, Zhou, \& Pourkarimi, (2016). Hence, the third hypothesis is developed as follows:

$\mathrm{H}_{3}$ : Transformational Leadership impacts on Employee Engagement

\section{Mediating Role of Employee Engagement between Transformational Leadership and Employee Performance}

A study conducted by Mariam (2020) has proved that engagement has a mediating effect on the relationship between transformational leadership behaviors on employee performance. So, the results explained that, all idealized influence, inspirational motivation, intellectual simulation, individual 
consideration and employee engagement were significant on the employee performance. Moreover, the findings indicated that, employee engagement mediates the relationship between leaders who have transformational leadership actions is a precondition for employees to be engaged, and also enhance the outcomes of the followers (Pourbarkhordari, Zhou, \& Pourkarimi, 2016).

Hence, the final hypothesis is developed as follows:

$\mathrm{H}_{4}$ : Employee Engagement mediates the relationship between Transformational Leadership and Employee Performance

\section{Methodology}

This research can be regarded as an analytical study and the investigation type is causal. This study gathered data in the chosen porcelain manufacturing companies' normal surroundings without regulating the internal or external factors. The survey was conducted among a sample of 260 production workers of selected porcelain manufacturing companies among a total population of 805 employees of three selected porcelain manufacturing companies. The sample was selected using simple random sampling method and the sample frame is the payroll register. The sample is derived with the Morgan \& Krejcie (1970) table. A set of questionnaires were distributed among the sample and the primary data was collected. A questionnaire was developed based on TL, EE and EP to gather information about employees from the selected porcelain manufacturing companies and five point Likert scales were used to measure the variables in the study. The secondary data was collected through numerous sources such as journals, published reports, internet and books relating to the topic. Statistical Package for the Social Sciences (SPSS) software package 23 was used to analyze the data and for data preparation and screening, reliability validity and relationships were tested. The developed hypotheses were tested by correlation analysis and simple regression analysis. Sobel test was used to measure the mediator effect of the study.

\section{Measures}

In the first part of this questionnaire a scale of 20 items has been developed referring to well accepted questions of other scholarly work which is used to measure TL practices by Bass \& Avolio (1995). There are four dimensions namely, idealized influence (both attributed and behavior), individualized consideration, intellectual stimulation, and inspirational motivation. 
The next section has been devoted to measure the EP aspects of the production workers. Referring to other scholarly work, a scale of 45 items has been developed for this purpose consisting of four components namely task performance, contextual performance (both interpersonal and organizational), adaptive performance and counter-productive work behavior (Koopmans, 2014).

The third part of the questionnaire consists of data about EE aspects of the production workers. Referring to other scholarly work, a scale of 5 items has been developed for this purpose consisting of three dimensions namely Vigor, Dedication and Absorption (Schaufeli \& Bakker, 2003).

The fourth part was used to gather data about demographic details of the production workers such as gender, age group and service period.

Items have been presented in Sinhala since the production workers are comfortable with the Sinhala language which they find easy to understand. Production workers were advised to record their agreements with the items through the five point Likert scales.

\section{Results}

\section{Reliability}

To ensure the internal consistency of measures Composite Reliability (CR) and Average Variance Extracted (AVE) were computed. CR is a measure of an internal consistency in scale items (Netemeyer, Bearden, \& Sharma, 2003). To ensure $\mathrm{CR}$ for the construct the value should be greater than 0.6 and AVE should be greater than 0.5 (Hair, Black , Babin , \& Anderson, 2014). As Table 1 indicates this criteria was met and the internal consistency of these measures was ensured.

Table 1: Measure of Internal Consistency

\begin{tabular}{lcccc}
\hline Variable & $\begin{array}{l}\text { No. of } \\
\text { Questions }\end{array}$ & $\begin{array}{l}\text { Factor Min- } \\
\text { Max }>\mathbf{0 . 3}\end{array}$ & CR >0.6 & AVE >0.5 \\
\hline $\begin{array}{l}\text { Transformational } \\
\text { Leadership }\end{array}$ & 20 & $0.835-0.466$ & 0.864 & 0.507 \\
Employee Performance & 45 & $0.921-0.465$ & 0.953 & 0.501 \\
& & & & \\
Employee Engagement & 17 & $0.847-0.514$ & 0.872 & 0.503 \\
\hline
\end{tabular}




\section{Validity}

Table 2: Discriminant Validity

\begin{tabular}{lccc}
\hline Variable & $\begin{array}{l}\text { Transformational } \\
\text { Leadership }\end{array}$ & $\begin{array}{l}\text { Employee } \\
\text { Performance }\end{array}$ & $\begin{array}{l}\text { Employee } \\
\text { Engagement }\end{array}$ \\
\hline $\begin{array}{l}\text { Transformational } \\
\text { Leadership }\end{array}$ & 0.427 & & \\
$\begin{array}{l}\text { Employee } \\
\text { Performance }\end{array}$ & 0.391 & 0.481 & \\
$\begin{array}{l}\text { Employee } \\
\text { Engagement }\end{array}$ & 0.262 & 0.345 & 0.463 \\
\hline
\end{tabular}

The above tables depict the data for discriminant validity and the results of the present study ensures the discriminant validity as the squared coefficient values are below the AVE (Hair, Black, Babin , \& Anderson, 2014).

Questionnaires were circulated among 260 production workers and 10 valid replies were not received, yielding a reply rate of $96 \%$.

\section{Demographic profile of the respondents}

Considering the demographic characteristics, $63 \%$ of females and $37 \%$ of male production workers are in the sample. Moreover, the largest age group representation is $37 \%$ who are reaching their retirement and the companies must think of their recruitments and this staff category is the skilled worker category. Then $31 \%$ and $23 \%$ represent the age $29-39$ and 18-28 categories, respectively. The age group representing 51-60 is $9 \%$ of the sample and that is significant. Further, service year-based categorization is significant as most senior, and junior samples are the same with $25 \%$ which expresses that the new recruits and the workers who are senior remained the same, but the middle category varied. $30 \%$ and $19 \%$ of the sample represents service year group 6-10 and 11-20 respectively.

\section{Hypotheses Testing}

\section{$H_{1}$ : Transformational leadership positively impacts on employee performance}

The impact of the TL on EP was measured by regression analysis.

Table 3: Model Summary $\mathbf{H}_{1}$

\begin{tabular}{lcccc}
\hline Model & $\mathbf{R}$ & R Square & Adjusted R Square & $\begin{array}{c}\text { Std. Error of the } \\
\text { Estimate }\end{array}$ \\
\hline 1 & $.625^{\mathrm{a}}$ & .391 & .388 & .36889 \\
\hline a. Predictors: (Constant), Transformational Leadership & &
\end{tabular}


The outcomes show (Table 3 ) that the multiple regression coefficients $(\mathrm{R})$ of the TL related independent variables and EP was 0.625 and the R Square was 0.391. It indicates that about 39.1 percent of the variance (R Square) in the EP is explicated by TL.

Table 4: ANOVA $\mathrm{H}_{1}$

\begin{tabular}{llrrrrr}
\hline \multicolumn{1}{l}{ Model } & \multicolumn{1}{c}{$\begin{array}{c}\text { Sum of } \\
\text { Squares }\end{array}$} & \multicolumn{1}{c}{ Df } & \multicolumn{1}{c}{$\begin{array}{c}\text { Mean } \\
\text { Square }\end{array}$} & \multicolumn{1}{c}{ F } & \multicolumn{1}{c}{ Sig. } \\
\hline 1 & Regression & 21.635 & 1 & 21.635 & 158.988 & $.000^{\mathrm{b}}$ \\
& Residual & 33.748 & 248 & .136 & & \\
& Total & 55.384 & 249 & & & \\
\hline
\end{tabular}

a. Dependent Variable: Employee Performance

b. Predictors: (Constant), Transformational Leadership

The p-value is below 0.05, which ensures which TL can be used to forecast EP (Table 4). Thus, results conclude that transformational leadership positively impacts employee performance.

\section{$\mathrm{H}_{2}$ : Employee Engagement positively impacts on employee performance}

Table 5: Model Summary $\mathrm{H}_{2}$

\begin{tabular}{lcccc}
\hline Model & R & R Square & Adjusted R Square & $\begin{array}{c}\text { Std. Error of the } \\
\text { Estimate }\end{array}$ \\
\hline 1 & $.587^{\mathrm{a}}$ & .345 & .342 & .38246 \\
\hline a. Predictors: (Constant) & employee engagement & &
\end{tabular}

Regression analysis was also run to measure the impact of EE on EP. Under the model summary (refer Table 5), value of R square is 0.345 , depicting that $\mathrm{EP}$ is explained by $34.5 \%$ through variation in $\mathrm{EE}$.

As per Table 6 given below, the p-value is below 0.05 which ensures which EE can be used to forecast EP. It is concluded that Employee engagement positively impacts employee performance.

Table 6: ANOVA $\mathrm{H}_{2}$

\begin{tabular}{llrrrrr}
\hline Model & \multicolumn{1}{c}{$\begin{array}{c}\text { Sum of } \\
\text { Squares }\end{array}$} & Df & Mean Square & F & \multicolumn{1}{c}{ Sig. } \\
\hline 1 & Regression & 19.107 & 1 & 19.107 & 130.626 & $.000^{\mathrm{b}}$ \\
& Residual & 36.276 & 248 & .146 & & \\
& Total & 55.384 & 249 & & & \\
\hline
\end{tabular}

a. Dependent Variable: Employee Performance

b. Predictors: (Constant), Employee Engagement 


\section{$H_{3}$ : Transformational leadership impacts on employee engagement.}

Regression analysis was also conducted to measure the impact of TL on EE. Under the model summary (Table 7) value of $\mathrm{R}$ square is 0.512 , depicting that EP is explained by $25.9 \%$ through variation in TL.

Table 7: Model Summary $\mathbf{H}_{3}$

\begin{tabular}{lcccc}
\hline Model & R & R Square & Adjusted R Square & $\begin{array}{c}\text { Std. Error of the } \\
\text { Estimate }\end{array}$ \\
\hline 1 & $.512^{\mathrm{a}}$ & .262 & .259 & .47533 \\
\hline
\end{tabular}

a. Predictors: (Constant), Transformational Leadership

The p-value is below 0.05 which ensures which TL can be used to forecast EE (refer Table 8). Therefore, it can be concluded that transformational leadership positively impacts employee engagement.

Table 8: ANOVA $\mathrm{H}_{3}$

\begin{tabular}{llrrrrr}
\hline Model & & Sum of & & & & \\
Squares & Df & Mean Square & \multicolumn{1}{c}{ F } & \multicolumn{1}{c}{ Sig. } \\
\hline 1 & Regression & 19.929 & 1 & 19.929 & 88.205 & $.000^{\mathrm{b}}$ \\
& Residual & 56.033 & 248 & .226 & & \\
& Total & 75.962 & 249 & & & \\
\hline
\end{tabular}

a. Dependent Variable: Employee Engagement

b. Predictors: (Constant), Transformational Leadership

$\mathrm{H}_{4}$ : Employee engagement mediates the relationship between Transformational leadership and employee performance

Multiple Regression Analysis and Sobel test were done to explore the mediating impact of EE between TL and EP. According to Sekaran \& Bougie (2016) when these two independent variables (TL and EE) are collectively regressed in opposition to the dependent variable (EP) with the purpose of explaining the variance in it, the sizes of the individual regression coefficients explain how much one unit of change will affect the dependent variable. This is based on the assumption that all the other independent variables remain unchanged. Based on the results of Multiple Regression Analysis, the Sobel test was done and Table 9 depicts the output of the analysis.

Table 9: Sobel Test

\begin{tabular}{ll}
\hline Item & Value \\
\hline Test Statistics & 14.540869 \\
Std. Error & 0.3072 \\
P value & 0.000 \\
\hline
\end{tabular}


Sobel test has three values and if the $\mathrm{P}$ value falls below 0.05 the predictor variable (TL) has an indirect effect on the measured variable (EP) and it is significant (Jacob , 2017). Therefore, it is culminated that EE is a mediator of the correlation between TL and EP.

\section{Discussion}

This is the first objective of the study, and the result has supported the first hypothesis. So, this concludes that TL has a positive impact on EP of production workers in selected porcelain manufacturing companies in Sri Lanka. Han, Oh, \& Kang, (2020), Jyoti \& Bhau (2015), Walumbwa \& Hartnell (2011) and Tohardi (2002) in their studies have found that TL has a constructive impact on EP.

This is the second objective of this study, and the result has supported the second hypothesis. So, this culminates that EE has a constructive effect on EP of production workers in chosen porcelain production factories in Sri Lanka. This relationship has been tested and proved several times by various studies conducted by (Harter, Hayes, \& Schmidt, 2002), (Richman, 2006), (Saks, 2006), (Choo, 2009), (Bakker \& Bal, 2010), (Chung \& Angeline, 2010) and (Bakker \& Demerouti, 2012).

The results indicate the significant positive impact of TL on EE. So, this concludes that TL has a positive impact on EE of production workers in selected porcelain manufacturing companies in Sri Lanka. Pourbarkhordari, Zhou, \& Pourkarimi, (2016), Xu \& Thomes (2011), Aryee \& Walumbuwa (2012) and Devi \& Narayanamma (2016) have tested and stated that there is a constructive correlation between transformational leadership and employee engagement in different contexts.

As per the Sobel test the $\mathrm{P}$ value is 0.000 which falls below 0.05 . The predictor variable (TL) has an indirect effect on the measured variable (EP) and it is significant. So, this concludes that EE is a mediator between TL and EP of manufacturing workers in selected porcelain production companies in Sri Lanka. Pourbarkhordari, Zhou, \& Pourkarimi, (2016), Md. Al-Amin, (2017), Hee, Ibrahim, Kowang, \& Fei, (2018) and Mariam (2020) have tested and concluded the mediating effect of EE on TL and EE and this hypothesis has been empirically proved. 


\section{Conclusion}

The study was based on the emerging and challenging sphere of Human Resource Management today, 'Transformational Leadership,' which is strategically relevant to the achievements of the organizations. The present paper has executed mainly to identify the impact of TL on EP amidst manufacturing workers of chosen porcelain producing organizations in Sri Lanka. To fill the existing research gap, this explanatory research was mainly conducted using correlational and regression analysis with SPSS for providing more meaning and clarifications over the context.

The findings have concluded not only a strong direct impact of TL on EP but also a significant indirect impact via EE. To get confirmation of the study, it has tested both TL and EP with EE separately under the hypotheses and has revealed a significant positive impact. According to the results, a mediation of EE between TL and EP, has been revealed.

The empirical link between TL and EP and the mediating role of EE is a major contribution of this study. These results of the study have provided an insight into the existing theory of TL and EP. Consequently, the study enlarges the EE theory by studying the relationship of TL on EP. The importance of these correlations or linkages has not been treated well in the local settings mainly in the factory environment. Therefore, the current study will be an eye opener for the leaders, and the management should revisit these concepts and grab the core of the relationships. Then they can absorb the idea of these dimensions and practice them as required. Especially there is a lack of research pertaining to Sri Lankan culture. The current study has contributed to the Human Resource Management literature from a theoretical perspective by examining TL on EP among the production workers of selected porcelain manufacturing companies in Sri Lanka. This study indicates a new avenue for the TL - EP link of which the direct and indirect paths were significant results of mediation between the constructs.

Further, it is suggested that the relationships can be tested for each dimension separately with the dependent variable employee performance. Moreover, the scope of the study needs to be expanded, creating more complex models that can include some other independent variable and test the indirect or direct relationship and the combined impact of these predictor variables on the measured variable. Apart from that the correlations can be tested for each dimension of employee performance as well. The levels of each dimension can 
be tested with reference to transformational leadership. Moreover, testing the follower's characteristics considered by both leader and follower as potential mediators or moderators of the effect of TL on EE and EP is suggested. Apart from that conducting studies with other leadership styles such as authentic leadership and servant leadership to identify the relationship with EE and EP is also proposed. Finally, the current study bridged the gaps in existing literature pertaining to the context of TL and its outcomes.

\section{Declaration of Conflicting Interests}

The authors declared no potential conflicts of interest with respect to the research, authorship, and publication of this article.

\section{References}

Anitha, J. (2014). Determinants of employee engagement and their impact on employee performance. International Journal of Productivity and Performance Management, 63(3), 308-323.

Aryee, S., \& Walumbuwa, F. (2012). Transformational Leadership, Innovative Behavior and Task Performance : Test of Mediation and Moderation processes. Human Performance, 25(1), 1-12.

Bacha, E. (2014). The relationship between transformational leadership, task performance and job Characteristics. Journal of Management Development, 33(4), 410-420.

Bakker, A., \& Bal, P. M. (2010). Weekly work engagement and performance: A study among starting teachers. Journal of Occupational and Organizational Psychology, 83(1), 189-206.

Bakker, A., \& Demerouti, E. (2012). Work engagement, performance, and active learning: The role of conscientiousness. Journal of Vocational Behavior, 80(2), 555-564.

Bass, B., \& Avolio, B. (1995). Multifactor leadership questionnaire: Manual leader form rater, and scoring key for MLQ (Form 5x-Short). Mind Garden, Redwood City, CA,.

Bates, S. (2004 ). Getting engaged. HR Magazine, 49(2), 44-51.

Baumruk, R. (2004). The missing link: the role of employee engagement in business success. Workspan, 47, 48-52.

Burns, J. (1978). Leadeship. New York: Harper \& Raw.

Butler, C., Stanton, E., \& Soane, E. (2015). Followers' personality, transformational leadership and performance. Sport, Business and Management: An International Journal, 5(1), 65-78. 
Choo, S. L. (2009). A study of the role of work engagement in promoting service-oriented organizational citizenship behavior in the Malaysian hotel sector. Global Business and Organizational Excellence, 35(4), 28-43.

Chung, N., \& Angeline, T. (2010). Does work engagement mediate the relationship between job resources and job performance of employees? African journal of business management, 4(9), 1837-1843.

Datche , E., \& Hazel, G. (2015). Effects of Transformational Leadership on Employee Engagement: The mediating role of employee engagement. International Journal of Management, 6(2), 01-08.

Devi , \& Narayanamma , L. (2016). Impact of Leadership Style on Employee Engagement. Pacific Business Review International, 1(1), 91-98.

Dixit, S., \& Arrawati, D. A. (2018). The Impact of Talent Management on Job Satisfaction and Employee Performance in Public Sector Banks of Rajasthan. International Journal of Creative Research Thoughts, 6(1), 426435.

Dvir, T., Eden, D., Bruce, J., \& Boas , S. (2002). Impact of Transformational Leadership on Follower Development and Performance: A Field Experiment. Academy of Management Journal, 45(4), 735-744.

Ghafoor, A., Syed, H., \& Qureshi, T. M. (2011). Transformational leadership, employee engagement and performance: Mediating effect of psychological ownership. African Journal of Business Management, 5(17), 7391-7403.

Groves, K. S., \& LaRocca, M. A. (2011). An Empirical Study of Leader Ethical Values, Transformational and Transactional Leadership, and Follower Attitudes Toward Corporate Social Responsibility. Journal of Business Ethics, 103, 511-528.

Hair, J., Black , W., Babin , B., \& Anderson. (2014). Multivariate Data Analysis, ,. Upper Saddle River: New Jersey: Prentice Hall.

Han, S. H., Oh, E. G., \& Kang, S. P. (2020). The link between transformational leadership and work-related performance: moderated-mediating roles of meaningfulness and job characteristics. Leadership \& Organization Development Journal, 41(4), 519 -533.

Harter , J., Hayes, T., \& Schmidt, F. (2002). Business-unit-level relationship between employee satisfaction, employee engagement, and business outcomes: A meta-analysis. Journal of Applied Psychology, 87(2), 268.

Hee, O. C., Ibrahim, R., Kowang, T. O., \& Fei, G. C. (2018). Employee Engagement as a Mediator Between Transformational Leadership and Employee Performance. Asian Journal of Scientific Research, 11(3), 441448 . 
Jacob , N. R. (2017). The SAGE Encyclopedia of Communication Research Methods. Thousand Oaks: SAGE Publications, Inc.

Jyoti, J., \& Bhau, S. (2015). Impact of transformational leadership on job performance: Mediating role of leader-member exchange and relational identification. SAGE Open, 5(4), 1-13.

Kahn, W. A. (1990). Psychological conditions of personal engagement and disengagement at work. Academy of Management Journal, 33, 692-724.

Koopmans, L. (2014). Measuring Individual Work Performance. Zutphen: CPI Koninklijke Wöhrmann.

Lockwood, N. (2007). Leveraging Employee Engagement for Competitive Advantage: HR's Strategic Role. Society for Human Resource Management Research Quarterly, 1(1), 1-12.

Macey , W. H., Schneider, B., \& Bar, K. M. (2009). The "Feel and Look" of Employee Engagement. In Employee Engagement: Tools for Analysis, $P$ ractice, and Competitive Advantage (pp. 19-42). Valtera Corporation.

Mariam, G. G. (2020). The Effect of Transformational leadership behavior on employee performance: mediation role of Employee Engagement (EE): Addis Ababa: Addis Ababa University.

Maslach, C. (2003). Job Burnout: New Directions in Research and Intervention. Current Directions in Psychological Science, 12(5), 189-192.

Md. Al-Amin. (2017). Transformational Leadership and Employee Performance Mediating effect of Employee Engagement. North South Business Review, $7(2), 28-40$.

Mone, E., \& London, M. (2010). Employee Engagement : Through Effective Performance Management- A Practical Guide for Managers.. Talyor \& Francis Group.

Morgan, D., \& Krejcie table, R. (1970). Determining sample size for research activities. Educational and Psychological Measurement, 30, 607-610.

Netemeyer, R., Bearden, W., \& Sharma, S. (2003). Scaling procedures: Issues and applications. Thousand Oaks, CA: Sage Publications.

Perera, G., \& Wijewardene, L. (2019). The Impact of Employee Engagement on Employee Performance in Sri Lankan Licensed Commercial Banks. Rajarata Journal of Social Sciences, 4(2), 27-40.

Pillai, R., \& Williams, E. A. (2004). Transformational leadership, self-efficacy, group cohesiveness, commitment, and performance. Journal of Organizational Change Management, 17(2), 144-159.

Pourbarkhordari, A., Zhou, E., \& Pourkarimi J. (2016). How Individual-focused Transformational Leadership Enhances Its Influence on Job Performance 
through Employee Work Engagement. International Journal of Business and Management, 11(2), 249.

Rich, B. L., \& Crawford, E. (2010). Job Engagement: Antecedents and Effects on Job Performance. The Academy of Management Journal, 53(3), 617-635.

Richman, A. (2006). Everyone wants an engaged workforce how can you create it? Workspan, 49(1), 36-39.

Rita, M., Payangan, O., Rante, Y., Tuhumena, R., \& Erari, A. (2018). Moderating effect of organizational citizenship behavior on the effect of organizational commitment, transformational leadership and work motivation on employee performance. International Journal of Law and Management, 60(4), 953-964.

Saks, A. M. (2006). Antecedents and Consequences of Employee Engagement. Journal of Managerial Psychology, 21(7), 600-619.

Salanova, M., Lorente, L., Chambel, M. J., \& Martı'nez, I. M. (2011). Linking transformational leadership to nurses' extra-role performance:the mediating role of self-efficacy and work engagement. Journal of Advanced Nursing, 67(10), 2256-2266.

Schaufeli, W., \& Bakker, A. (2003). Utrech work engagement scale Piliminary Manual. Utrecht University.

Sekaran , U., \& Bougie, R. (2016). Research Methods for Business A skill Building Approach. United Kingdom: John Wiley \& Sons Ltd.

Sun, L. (2019). Employee Engagement: A Literature Review. International Journal of Human Resource Studies, 9(1), 63 -80.

Tohardi, A. (2002). Practical understanding of human resource management. University of Tanjung Pura, Bandung, Mandar Maju.

Viswesvaran, C., \& Ones, D. (2000). Perspectives on Models of Job Performance. International Journal of Selection and Assessment, 8(4), 216226.

Walumbwa, F., \& Hartnell, C. (2011). Understanding transformational leadership-employee performance links: the role of relational identification and self-efficacy. Journal of Occupational and Organizational Psychology, 84(1), 153-172.

Xie, W. (2006). Engagement (01 ed.). Beijing: China Business Press.

$\mathrm{Xu}$, J., \& Thomes, S. (2011). How can leaders achieve high employee engagement? Leadership Organization Development Journal, 32, 399 - 416.

Zhu, W., Avolio, B. J., \& Walumbwa, F. O. (2009). Moderating Role of Follower Characteristics With Transformational Leadership and Follower Work Engagement. Group \& Organization Management, 34(5), 590-619. 